Martínez, B., López Camacho, R., Castillo, L.S., \& Bernal, R. (2021). Phenology of the endangered palm Ceroxylon quindiuense (Arecaceae) along an altitudinal gradient in Colombia. Revista de Biología Tropical, 69(2), 649-664. https://doi.org/10.15517/rbt.v69i2.44835

https://doi.org/10.15517/rbt.v69i2.44835

\title{
Phenology of the endangered palm Ceroxylon quindiuense (Arecaceae) along an altitudinal gradient in Colombia
}

Blanca Martínez ${ }^{1 *}$; (D) https://orcid.org/0000-0002-7074-3534

René López Camacho1; (D https://orcid.org/0000-0003-2026-0371

Luis Santiago Castillo; (D https://orcid.org/0000-0003-2193-7516

Rodrigo Bernal'3; (D) https://orcid.org/0000-0002-9832-8498

1. Universidad Distrital Francisco José de Caldas, Bogotá, Colombia; bamartinezh@correo.udistrital.edu.co (*Correspondence), rlopezc@udistrital.edu.co

2. Instituto de Investigación de Recursos Biológicos Alexander von Humboldt, Bogotá, Colombia; 1castillo@humboldt.org.co

3. Reserva Natural Guadualito, Montenegro, Quindío, Colombia; rgbernalg@gmail.com

$$
\text { Received 27-XI-2020. Corrected 20-III-2021. Accepted 18-V-2021. }
$$

\begin{abstract}
Introduction: Understanding the phenology of plant populations is vital for their conservation and management. We studied the vegetative and reproductive phenology of the endangered palm Ceroxylon quindiuense along an altitudinal gradient in the Central Cordillera of Colombia. Objective: We describe the leaf production rate, and flowering and fruiting cycles, and calculate food offer for the fauna, as a tool for the proper management of the palm. Methods: At each sampling site (2400, 2600, 2800, 3000 m.a.s.1.), we marked 40 adult individuals (20 pistillate, 20 staminate), which we followed bimonthly for 24 months. We studied leaf production by counting fallen leaves. We followed flower and fruit production through observations with binoculars and photographs. Results: Each adult individual produced, on average, one leaf every 69 days. Although isolated individuals flowered throughout the year, most palms flowered synchronously at each elevation in October 2016-August 2017 and in August 2018-February 2019 and had ripe fruits 7-13 months later. Flowering started at $2600 \mathrm{~m}$, followed by 2800 and $3000 \mathrm{~m}$. Palms at $2400 \mathrm{~m}$, the lower limit of the palm stands in the area, showed a singular behavior, with scarce flower and fruit production, some individuals that changed sex, and a higher proportion of pistillate palms. Each palm produced 1-11 $(\overline{\mathrm{x}}=5.3, \mathrm{SD}=2.2)$ inflorescences and 1-10 $(\overline{\mathrm{x}}=5.3, \mathrm{SD}=2.2)$ infructescences. The average number of fruits per infructescence was 4465 (SD =1488). With an estimated population of adult palms between 256000 and 600000 and an overall ratio of pistillate: staminate individuals $1: 1$ or $1: 2$, total fruit production in the area during each fruiting period is estimated as 2.0-7.1 billion fruits. Conclusions: The huge number of flowers and fruits and their gradual availability along the altitudinal gradient have a major impact on the spatial and temporal distribution of food offer for fauna associated with the palm.
\end{abstract}

Key words: altitudinal gradient; flowering; fruiting; leaf production; palm phenology.

Palms are an important element in the dynamics of tropical ecosystems: e.g., by influencing the distribution and behavior of animals, which could affect other ecosystem functions, such as plant regeneration (Salm, Jalles-Filho,
\& Schuck-Paim, 2005; Beck, 2007; Keuroghlian \& Eaton, 2009) and soil properties (Young, Raab, McCauley, Briggs, \& Dirso, 2010). Palms are a vital food source for many animal species (e.g., Zona \& Henderson, 1989; Peres, 
1994; Galetti, Ziparro, \& Morellato, 1999; Scariot, 1999; Genini, Galetti, \& Morellato, 2009; Giombini, Bravo, \& Tosto, 2016). They also play an important role for human populations, which use them as a source of food, raw construction materials, and for making a variety of implements, among many other uses (e.g., Bernal, 1992; Henderson, Galeano, \& Bernal, 1995; Johnson, 2011; Bernal \& Galeano, 2013).

The Quindío wax palm, Ceroxylon quindiuense, is an abundant species in the cloud forests of Colombia and Perú. In Colombia, it grows in the three Andean ranges, although it is more abundant in the Central Cordillera. Its largest populations are located in the Tochecito River basin, in the municipalities of Cajamarca and Ibagué, Department of Tolima (Bernal, Galeano, \& Sanín, 2015), where the number of adults has been estimated between 256000 (Jiménez, 2017) and 600000 individuals (Bernal et al., 2015; Instituto Humboldt, 2016).

C. quindiuense is recognized worldwide for being the world's tallest palm, reaching $60 \mathrm{~m}$ in height (Bernal, Martínez, \& Sanín, 2018), and Colombia's national tree. It is considered Endangered (EN) (Galeano \& Bernal, 2005), mainly due to habitat transformation as result of human activities, especially agricultural expansion. Conservation of this species requires a thorough understanding of its population dynamics and phenological cycles, as well as of the underlying factors.

Phenology studies the occurrence of repetitive biological events and the biotic and abiotic environmental factors that control them. A better understanding of the phenology of a plant species makes it possible to evaluate, for instance, flower and fruit availability for the local fauna (e.g., Morellato et al., 2000; Cabrera \& Wallace, 2007), or litter production for soil formation and nutrient input (e.g., Vitousek, 1984; Sayer et al., 2020), all of which are fundamental aspects to understand forest dynamics.

Although the conservation and management plan for $C$. quindiuense in Colombia (Bernal et al., 2015) stresses the need to conduct phenological studies, only a single short-term work performed by Girón-Vanderhuck, Salazar, and Agudelo (2001a) is available. In this paper we present the results of a two-year phenological study carried out along an altitudinal gradient in the Tochecito River basin, in the Central Cordillera of Colombia, where the largest palm stands of this species are found. We describe leaf production rate, and flowering and fruiting cycles, and contrast them among elevations. We also calculate the food offer for the fauna, as a tool for the proper management of this species in the area. As temperature in the tropical Andes decreases by ca. $0.6^{\circ}$ per $100 \mathrm{~m}$ increase in elevation (Ramírez, Roldán, \& Yépez, 2004), this change in temperature is expected to influence phenology along the gradient. Because no similar studies appear to have been made in the Andes, we expected differences in parameters to occur, but did not have any clue of the direction of variation, if any. We hypothesized that the flowering sequence along the gradient would somehow be similar to the sequential flowering of several Ceroxylon species, described by Carreño-Barrera, Madriñán, and NúñezAvellaneda (2013).

\section{MATERIALS AND METHODS}

Study area: The study area is in the Tochecito River basin, in the Department of Tolima, on the Eastern slope of the Central Cordillera of Colombia ( $4^{\circ} 30^{\prime} 45^{\prime \prime}-4^{\circ} 31^{\prime} 34^{\prime \prime}$ $\left.\mathrm{N} \& 75^{\circ} 30^{\prime} 29^{\prime \prime}-75^{\circ} 26^{\prime} 31^{\prime \prime} \mathrm{W}\right)$, between 2400 and $3000 \mathrm{~m}$ elevation (Fig. 1). It is a mountain area of 8890 ha, of which $43 \%$ have some type of palm cover (cloud forest remnants or secondary forests dominated by very dense palm stands, cloud forest remnants or secondary forests with some palms, matrix of pastures and crops with very dense palm stands, and matrix of pastures and crops with some palms) (Instituto Humboldt, 2016). The rainfall regime is bimodal, with the rainiest period between June and November, and the driest period between February and March (IDEAM, 2020). 


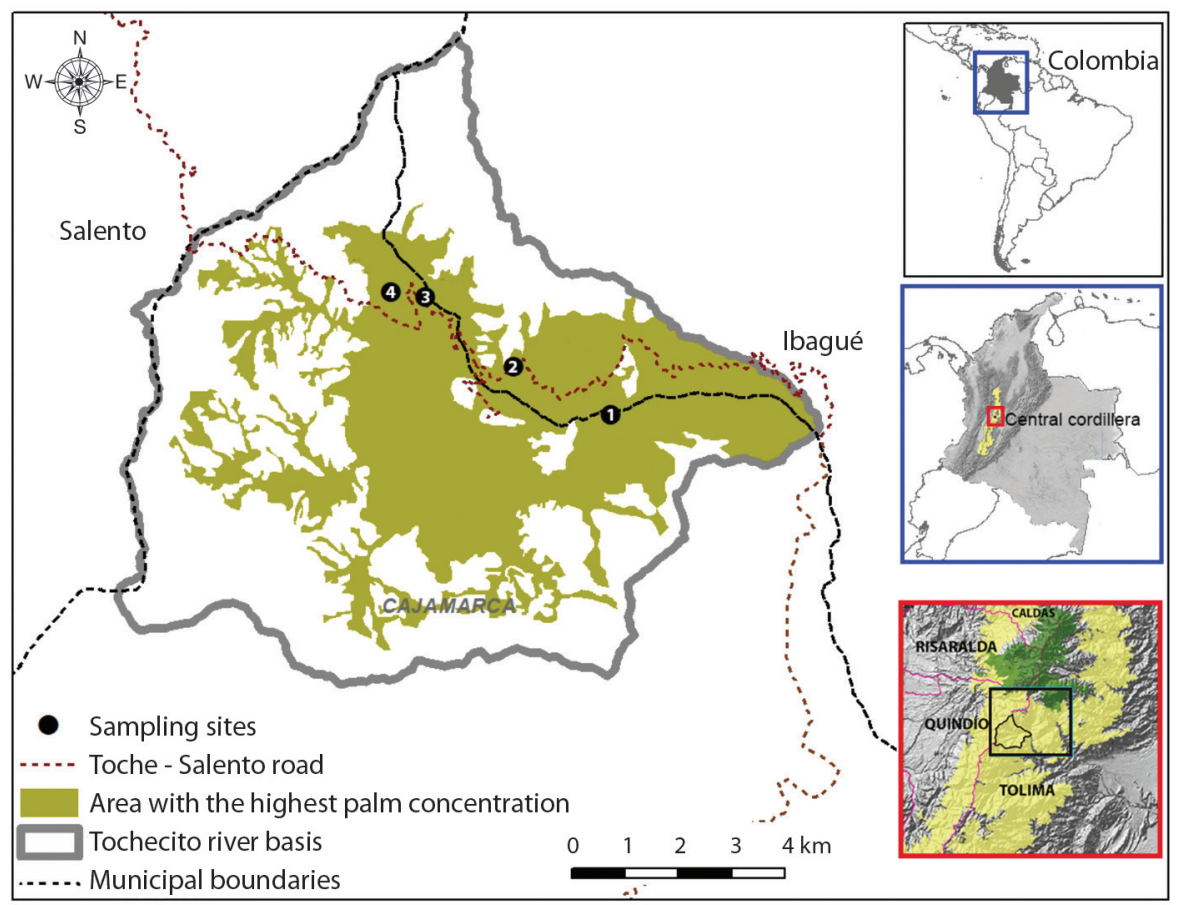

Fig. 1. Location of the Ceroxylon quindiuense study area in the Central Cordillera of Colombia. Sampling sites at different altitudes: 1: Las Cruces (2400 m.a.s.1.); 2: Galleguito (2 600 m.a.s.1.); 3-4: La Carbonera (2800 and 3000 m.a.s.1.). Based on IGAC (2014) layers.

Study species: Ceroxylon quindiuense is a single-stemmed palm, reaching up to $60 \mathrm{~m}$ in height (Bernal et al., 2018) and $36 \mathrm{~cm}$ in diameter at breast height. Its crown consists of 12-27 blue-green leaves, with the pinnae covered on the underside by a woolly whitish indument. It is a dioecious species, although, in some cases, individuals change sex (Martínez, Sanín, Castillo, López, \& Bernal, 2018). The inflorescences are interfoliar, repeatedly branched, supported by a long peduncle, and bearing several thousand small, whitish flowers, which have anthesis almost simultaneously for one to a few days (personal observation, 2012 to 2020; Carreño-Barrera et al., 2013). Although the flowers of both sexes look very similar, staminate and pistillate inflorescences are easily recognized, even from a great distance. Pistillate inflorescences remain with their rachillae completely extended, at a wide angle with the rachis, even after fruiting and falling to the ground. In the staminate inflorescences, on the other hand, the rachillae are closely appressed to the rachis after anthesis, so that the old inflorescences have a broom-like appearance (Martínez et al., 2018). Each palm produces several infructescences simultaneously and each one bears thousands of spherical fruits, $1-2 \mathrm{~cm}$ in diameter, smooth and orange-red when ripe (Galeano \& Bernal, 2010; Sanín \& Galeano, 2011).

Data collection: We surveyed four sites located at intervals of 200 meters along an elevation gradient starting at 2400 m.a.s.l. and ending at 3000 m.a.s.l., (2 400, 2600, 2800 and 3000 m.a.s.1., Fig. 1). At each elevation, individuals were selected within a range of $+/-25$ $\mathrm{m}$ with respect to the elevation value. The 2400 $\mathrm{m}$ site was established in a secondary forest and 

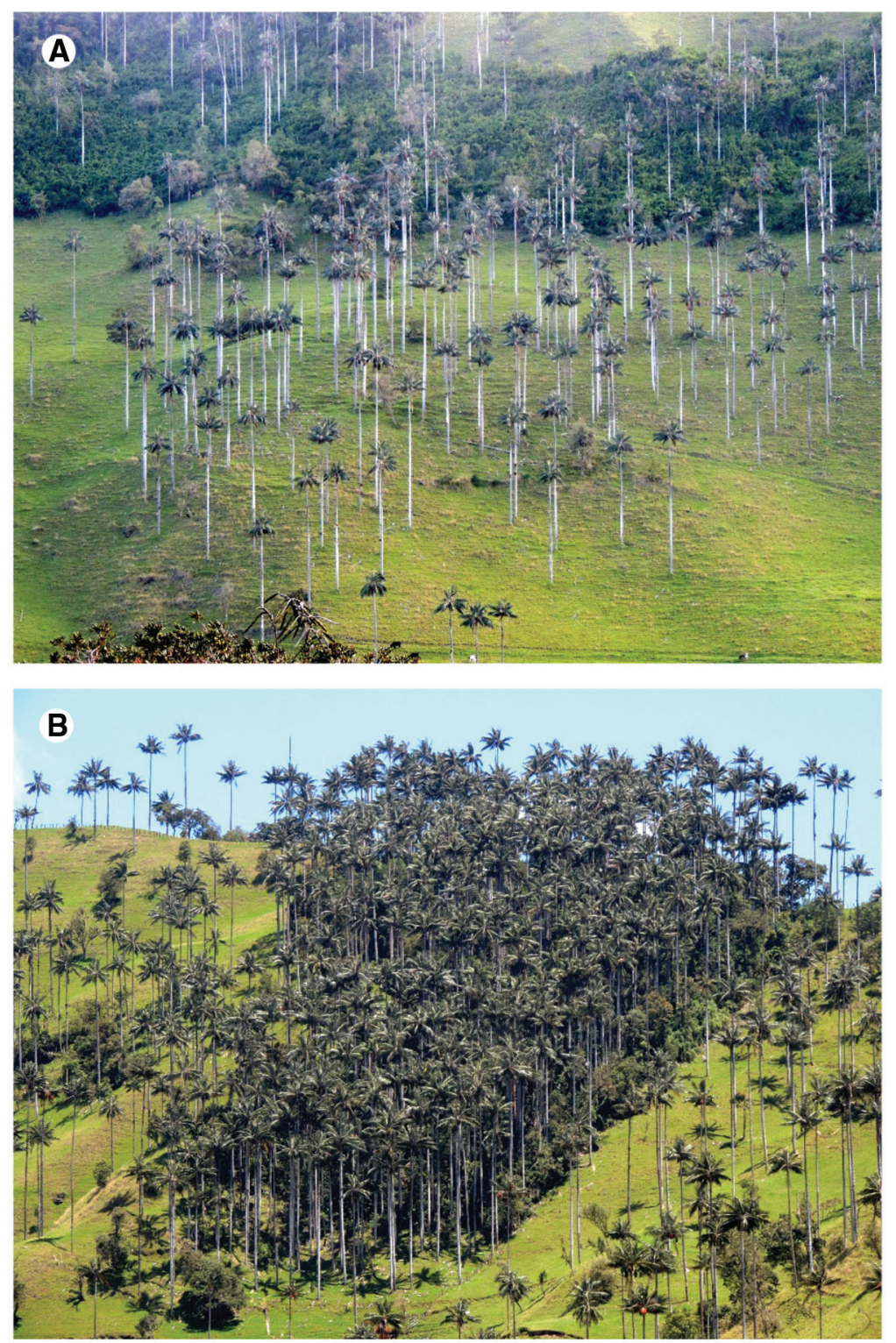

Fig. 2. Ceroxylon quindiuense at the Tochecito River basin, Colombia. A. Palms surviving in pastures; B. Palm-dominated forest fragment.

the remaining sites were established in pastures with isolated palm trees, overgrown pastures, or forest edge (Fig. 2).

Adult Quindío wax palms emerge out of the forest canopy. For this reason, observing the crowns from within the forest is almost impossible; however, casual observations in the area over several years have shown that palms growing in both forests and pastures follow the same phenological pattern (timing, duration, frequency and intensity in leafing, flowering, and fruiting) (personal observation from 2005 through 2018). The individuals in this study were thus selected in clean pastures with cattle 
presence, overgrown pastures, or secondary forests, in which the palm crowns were visible (Fig. 2).

At each sampling site, 40 adult individuals 20-40 meters tall were chosen (20 staminate and 20 pistillate), taking a random initial individual and thereafter selecting the closest neighbor that was within the elevation belt of $50 \mathrm{~m}$ described above. Each individual was marked with an aluminum plate tied to the stem with a nylon thread, at a height of $1.6 \mathrm{~m}$ above the ground.

We made observations of reproductive structures using binoculars and photographs. The phenological data were recorded bimonthly between October 2017 and October 2019. In each of the selected individuals, the presence of reproductive structures was evaluated, taking into account the following phenophases: bud: reproductive structure wrapped in the peduncular bracts; flower: inflorescence composed of yellowish-white flowers at anthesis; old inflorescence: inflorescence in which almost $100 \%$ of the flowers have fallen and only the axes remain; immature fruits: infructescence with well-formed fruits, which have reached their final size but are still green; ripe fruits: infructescence in which almost all fruits are orange-red; old infructescence: infructescence that has lost $100 \%$ of its fruits and of which only the axes remain. During the observations, the ripe fruits category was divided into three subcategories, which were pooled for some of the analyses: ripe fruits 1: ripe infructescence in which more than $50 \%$ of the fruits persist; ripe fruits 2: ripe infructescence in which $20-50 \%$ of the fruits persist; ripe fruits 3 : ripe infructescence in which less than $20 \%$ of the fruits persist.

To follow the development of each of the reproductive structures, we took its position in the crown, choosing a fixed point in the terrain, from which the crown was seen as a clock dial, in which the structures were located in a clockwise direction, starting from six. The apex of the reproductive structure was taken as an indicator of the position on the dial. Each crown was observed from different angles to corroborate the structure's stage.

In addition to the reproductive stage, we recorded leaf production for each individual at altitudes of 2600,2800 , and $3000 \mathrm{~m}$. To do this, we followed 84 palms $(37,18$ and 29 individuals, respectively) over 18 months, counting, in each observation, the number of fallen leaves found around the palm's base. Once counted, fallen leaves were removed from the place to facilitate the next count. The number of fallen leaves between two observations was assumed to correspond to the number of leaves produced by the palm, since in the long term, the number of leaves on the crown remains constant (Tomlinson, 1963; Corner, 1966). Leaf production was not followed at the $2400 \mathrm{~m}$ site, as it lay on a very steep and inaccessible slope, which could be observed with binoculars and photographed, but in which the palms were inaccessible. Additionally, to know the contribution of biomass to the basin, we weighed all fallen leaves and old inflorescences and infructescences in the August 2019 observation. To estimate the number of fruits per infructescence, we randomly took six ripe infructescences fallen on the ground, from which we removed and counted all fruits. The fresh and dry weight of 100 fruits and their respective seeds were obtained, to calculate the total weight of the food supply offered by the palms.

Data analysis: Since palms present a structure composed of successive leaf-inflorescence-internode modules (Henderson, 2002), the development of each of their reproductive structures (buds, inflorescences, and infructescences) can be followed individually. As floral anthesis lasts only 2-3 days (personal observation from 2005 through 2018; CarreñoBarrera et al., 2013; Carreño-Barrera, NúñezAvellaneda, Sanín, \& Campos, 2020), and our observations were bimonthly, the probability of finding an inflorescence at anthesis during the observation period was low. For this reason, for each reproductive structure, the month of its flowering was interpolated between the last 
observation in which it was found in bud and the appearance of a structure with early developing fruits.

On the other hand, the total development time from flower to ripe fruits observed in 211 inflorescences at the 2600, 2800, and $3000 \mathrm{~m}$ elevations was taken as the median value for each site. This value was applied retrospectively to those structures that were in ripe fruit at the time when our observations started in October 2017, and prospectively to those in flowering in October 2019. In this way, the data taken to the pistillate individuals for 24 months allowed us to extrapolate the behavior of the flowering cycles twelve months backwards until October 2016, and eight months forward, until June 2020. Thus, flowering and fruiting cycles in pistillate individuals in this study cover almost four years. At the $2400 \mathrm{~m}$ elevation, only the data of the single individual that had a complete cycle were used. For the staminate inflorescences, due to their ephemeral nature, no extrapolations or interpolations could be done.

The duration of the fruiting period was determined as the number of months between the appearance of ripe infructescences in any of the three states (ripe fruits 1,2 or 3) and the fall of all fruits (old infructescence). To determine the fruiting peaks at each elevation, only ripe infructescences with almost $100 \%$ of their fruits (ripe fruits 1) were considered, to avoid counting the same infructescence in two consecutive observations.

The development time of female reproductive structures from pistillate flower to ripe fruit at each elevation was taken as the median number of months it took the pistillate inflorescences for which a complete cycle was observed (i.e., from the appearance of flowers to the appearance of ripe fruits 1).

As our data were not normally distributed, we used Kruskal-Wallis tests to compare the development time from flower to ripe fruit, and leaf production between the different elevations, and between sexes. We used Spearman correlation to correlate precipitation data with flowering and fruiting. We used circular statistics to evaluate seasonality in the C. quindiuense reproductive phenology and also to find differences in the seasonal patterns among altitudes. This circular statistic requires months to be transformed to angles (Zar, 1999; Morellato et al., 2000). As our field observations indicate that $C$. quindiuense shows a 2-year reproductive cycle, we used intervals of 15 degrees between months, being November 2019: $7.5^{\circ}$ and October 2019: $352.5^{\circ}$. We dismissed the October 2017 data in the circular analysis as we only considered a 24-month cycle in the statistics.

The circular statistical analyses were done using the ORIANA v.4.02 software (Kovach, 1994). The evaluated parameters were: mean vector, length of mean vector, median, and circular standard deviation. As some of our data are not normally distributed (they do not match the von Mises distribution), we used the Rao's non-parametric test (U) for uniformity at each elevation and for every type of reproductive structure (i.e., pistillate inflorescences, staminate inflorescences and infructescences). This test points out the probability of the data being randomly distributed. If the test rejects the hypothesis of uniformity, it means that the studied population shows seasonality in its reproduction. Then, we used the Watson $\mathrm{U}^{2}$ non-parametric test to compare seasonality among the different elevations and for each type of reproductive structure. Here, the hypothesis is that the mean vectors of the two sampled populations are not significantly different. If this hypothesis is rejected, it means the reproductive phenology is asynchronical between altitudes (Morellato et al., 2000). Only field data were included in the statistical treatments.

\section{RESULTS}

Development time of the 211 reproductive structures from pistillate flower to ripe fruit ranged from seven to eleven months and differed among sites (Table 1). It took longer for the individuals at 2800 and $3000 \mathrm{~m}$ than for those at 2400 and $2600 \mathrm{~m}\left(\chi^{2}=84.737\right)$. There 
TABLE 1

Development time of reproductive structures of Ceroxylon quindiuense in Tochecito, Tolima, Colombia, from pistillate flower to ripe fruit

\begin{tabular}{cccc}
$\begin{array}{c}\text { Elevation } \\
\text { (m.a.s.1.) }\end{array}$ & $\begin{array}{c}\text { Number of inflorescences with a full cycle observed } \\
\text { (number of individuals) }\end{array}$ & \multicolumn{2}{c}{ Duration (Months) } \\
2400 & $1(1)$ & 7 & Median \\
2600 & $50(11)$ & $7-11$ & 8 \\
2800 & $74(13)$ & $8-13$ & 11 \\
3000 & $86(14)$ & $8-12$ & 11 \\
\hline
\end{tabular}

were significant differences between 2600 and $2800 \mathrm{~m}(\mathrm{P}=7.3 \mathrm{e}-14)$ and between 2600 and $3000 \mathrm{~m}(\mathrm{P}=2.2 \mathrm{e}-16)$, but not between 2800 and $3000 \mathrm{~m}$.

The observed events and the corresponding extrapolations showed that between October 2016 and June 2020 there were two major pistillate flowering events and two major fruiting events in the Tochecito River basin. The flowering events happened between October 2016 and August 2017 and between August 2018 and February 2019. The fruiting events took place between September 2017 and April 2018 and between May 2019 and January 2020 (Fig. 3).
During the 24 months analyzed with circular statistics, flowering and fruiting showed a seasonal behavior for all the elevations (Rao's Spacing Test (U) $\mathrm{P}<0.01$, length of mean vector $>0.6)$. Only female palms at 2400 showed no flowering peaks $(\mathrm{U}=180,0.1>\mathrm{P}>0.01)$, possibly explained by the low number of pistillate flowers recorded at this site (6 female inflorescences) (Table 2). Furthermore, flowering and fruiting peak events were significantly different among all elevations (Watson $\mathrm{U}^{2}$ test, Table 3), supporting the idea that this palm population has an altitudinally sequential reproductive phenology (Table 3 ).

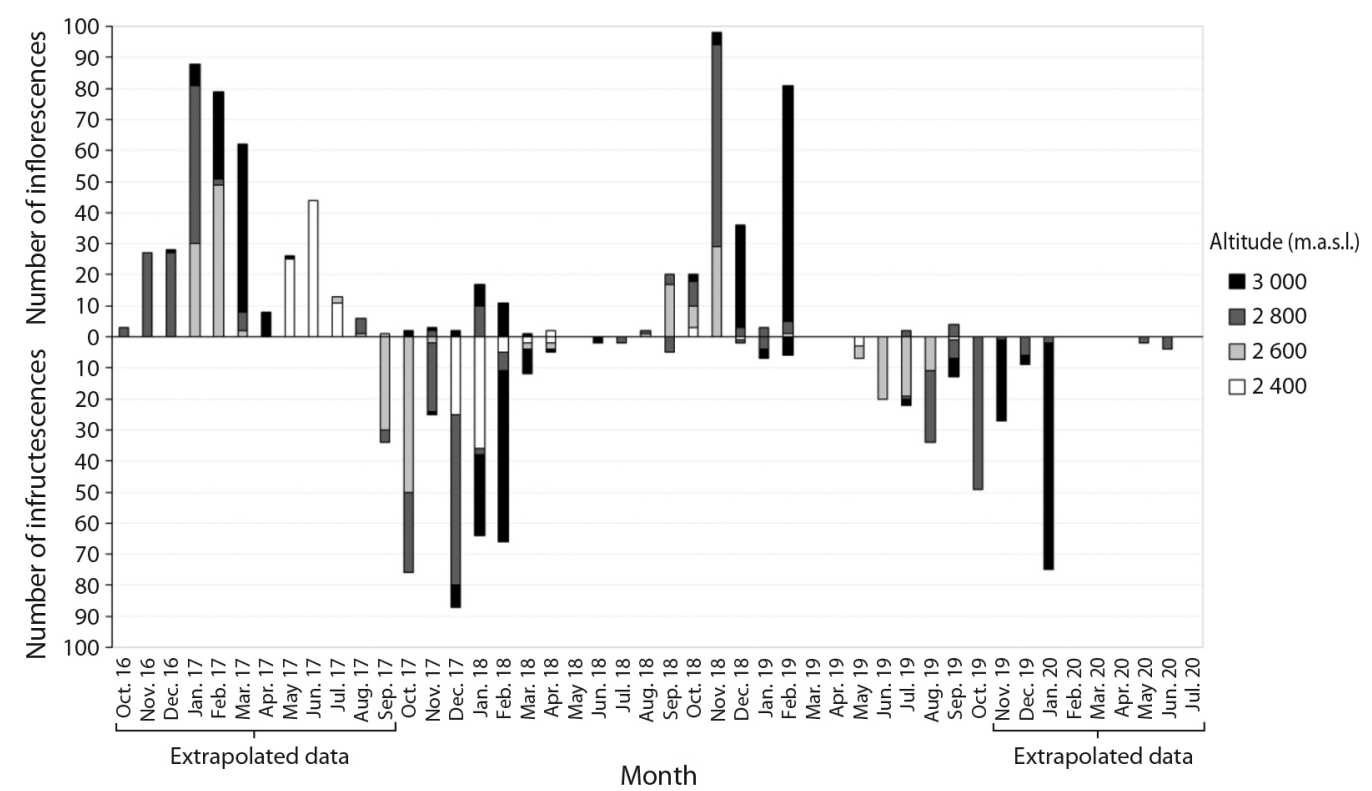

Fig. 3. Number of pistillate inflorescences and mature infructescences of Ceroxylon quindiuense at the Tochecito River basin, Colombia, at four elevations (2400 to 3000 m.a.s.1.), between 2016 and 2020. 
TABLE 2

Descriptive and circular statistics for the 24-month reproductive phenological cycle of Ceroxylon quindiuense in Tochecito, Tolima, Colombia

\begin{tabular}{|c|c|c|c|c|c|c|c|}
\hline $\begin{array}{l}\text { Elevation } \\
\text { (m.a.s.1.) }\end{array}$ & $\begin{array}{l}\text { Observations } \\
\text { (N) }\end{array}$ & $\begin{array}{l}\text { Mean vector } \\
\text { (month-year) }\end{array}$ & $\begin{array}{l}\text { Length of mean } \\
\text { vector (r) }\end{array}$ & $\begin{array}{c}\text { Median } \\
\text { (month-year) }\end{array}$ & $\begin{array}{l}\text { Circular } \\
\text { SD }\end{array}$ & $\begin{array}{c}\text { Rao's Spacing } \\
\text { Test (U) }\end{array}$ & $\begin{array}{c}\text { Rao's Spacing } \\
\text { Test (p) }\end{array}$ \\
\hline \multicolumn{8}{|c|}{ Staminate inflorescences } \\
\hline 2400 & 12 & $\begin{array}{c}95.6^{\circ} \\
\text { (May-18) }\end{array}$ & 0.718 & $\begin{array}{c}67.5^{\circ} \\
(\text { Mar-18) }\end{array}$ & $46.6^{\circ}$ & 255 & $<0.01$ \\
\hline 2600 & 114 & $\begin{array}{c}158.3^{\circ} \\
(\text { Sep-18) }\end{array}$ & 0.583 & $\begin{array}{c}172.5^{\circ} \\
(\text { Oct-18) }\end{array}$ & $59.5^{\circ}$ & 315.789 & $<0.01$ \\
\hline 2800 & 143 & $\begin{array}{c}157.3^{\circ} \\
\text { (Sep-18) }\end{array}$ & 0.292 & $\begin{array}{c}187.5^{\circ} \\
\text { (Nov-18) }\end{array}$ & $89.9^{\circ}$ & 322.238 & $<0.01$ \\
\hline 3000 & 168 & $\begin{array}{c}183.9^{\circ} \\
(\text { Nov-18) }\end{array}$ & 0.164 & $\begin{array}{c}202.5^{\circ} \\
(\text { Dec-18) }\end{array}$ & $109.0^{\circ}$ & 317.143 & $<0.01$ \\
\hline \multicolumn{8}{|c|}{ Pistillate inflorescences } \\
\hline 2400 & 6 & $\begin{array}{c}154.6^{\circ} \\
\text { (Sep-18) }\end{array}$ & 0.613 & $\begin{array}{c}172.5^{\circ} \\
(\text { Oct-18) }\end{array}$ & $56.7^{\circ}$ & 180 & $0.10>\mathrm{P}>0.05$ \\
\hline 2600 & 54 & $\begin{array}{c}175.4^{\circ} \\
(\text { Oct-18) }\end{array}$ & 0.97 & $\begin{array}{c}187.5^{\circ} \\
(\mathrm{Nov}-18)\end{array}$ & $14.2^{\circ}$ & 333.333 & $<0.01$ \\
\hline 2800 & 104 & $\begin{array}{c}186.9^{\circ} \\
\text { (Nov-18) }\end{array}$ & 0.655 & $\begin{array}{c}187.5^{\circ} \\
\text { (Nov-18) }\end{array}$ & $52.7^{\circ}$ & 321.923 & $<0.01$ \\
\hline 3000 & 137 & $\begin{array}{c}221.0^{\circ} \\
(\mathrm{Jan}-19)\end{array}$ & 0.65 & $\begin{array}{c}232.5^{\circ} \\
(\text { Feb-19) }\end{array}$ & $53.2^{\circ}$ & 336.35 & $<0.01$ \\
\hline \multicolumn{8}{|c|}{ Infructescences } \\
\hline 2400 & 75 & $\begin{array}{c}32.3^{\circ} \\
(\text { Jan-18) }\end{array}$ & 0.886 & $\begin{array}{c}37.5^{\circ} \\
(\text { Jan-18) }\end{array}$ & $28.2^{\circ}$ & 321.6 & $<0.01$ \\
\hline 2600 & 60 & $\begin{array}{c}308.1^{\circ} \\
(\text { Jul-19) }\end{array}$ & 0.85 & $\begin{array}{c}307.5^{\circ} \\
\text { (Jul-19) }\end{array}$ & $32.7^{\circ}$ & 318 & $<0.01$ \\
\hline 2800 & 176 & $\begin{array}{c}2.9^{\circ} \\
\text { (Nov-17) }\end{array}$ & 0.802 & $\begin{array}{c}7.5^{\circ} \\
\text { (Nov-17) }\end{array}$ & $38.1^{\circ}$ & 335.455 & $<0.01$ \\
\hline 3000 & 117 & $\begin{array}{c}43.8^{\circ} \\
(\mathrm{Jan}-18)\end{array}$ & 0.766 & $\begin{array}{c}52.5^{\circ} \\
(\text { Feb-18) }\end{array}$ & $41.8^{\circ}$ & 326.154 & $<0.01$ \\
\hline
\end{tabular}

TABLE 3

Square matrix showing the Watson $\mathrm{U}^{2}$ test results for each reproductive structure and comparing altitudes for the 24-month reproductive phenological cycle of Ceroxylon quindiuense in Tochecito, Tolima, Colombia

\begin{tabular}{|c|c|c|c|c|}
\hline Elevation (m.a.s.1.) & 2400 & 2600 & 2800 & 3000 \\
\hline 2400 & - & $\begin{array}{l}\mathrm{SF}<0.05 \\
\mathrm{PF}<0.05 \\
\mathrm{IF}<0.001\end{array}$ & $\begin{array}{c}\mathrm{SF}<0.001 \\
\mathrm{PF}<0.05 \\
\mathrm{IF}<0.001\end{array}$ & $\begin{array}{c}\mathrm{SF}<0.002 \\
\mathrm{PF}<0.01 \\
\mathrm{IF}<0.001\end{array}$ \\
\hline 2600 & $\begin{array}{l}\text { SF: } 0.225 \\
\text { PF: } 0.225 \\
\text { IF: } 2.947\end{array}$ & - & $\begin{array}{c}\mathrm{SF}<0.001 \\
\mathrm{PF}<0.02 \\
\mathrm{IF}<0.001\end{array}$ & All $<0.001$ \\
\hline 2800 & $\begin{array}{l}\text { SF: } 0.524 \\
\text { PF: } 0.206 \\
\text { IF: } 2.486\end{array}$ & $\begin{array}{l}\text { SF: } 1.098 \\
\text { PF: } 0.243 \\
\text { IF: } 3.358\end{array}$ & - & All $<0.001$ \\
\hline 3000 & $\begin{array}{l}\text { SF: } 0.359 \\
\text { PF: } 0.286 \\
\text { IF: } 1.718\end{array}$ & $\begin{array}{l}\text { SF: } 1.772 \\
\text { PF: } 4.22 \\
\text { IF: } 3.629\end{array}$ & $\begin{array}{l}\text { SF: } 0.461 \\
\text { PF: } 5.444 \\
\text { IF: } 4.984\end{array}$ & - \\
\hline
\end{tabular}

$\mathrm{U}^{2}$ scores (lower half) and probabilities (upper half). SF: Staminate inflorescences, PF: Pistillate inflorescences, and IF: Infructescences. 
During each flowering and fruiting event, the peaks were not simultaneous at the different elevations. For the first major event (20162017), the flowering peak took place first at $2800 \mathrm{~m}$ in January 2017, followed by $2600 \mathrm{~m}$ in February, $3000 \mathrm{~m}$ in March and ending at $2400 \mathrm{~m}$ in June. However, because the flowerto-fruit development time was different among elevations (Table 1), the order of appearance of the fruiting peaks along the gradient was not the same as that of flowering peaks. The first peak of ripe fruits started at $2600 \mathrm{~m}$ in October 2017 , and from there advanced upward to 2800 $\mathrm{m}$ (December) and downward to $2400 \mathrm{~m}$ (January 2018), ending at $3000 \mathrm{~m}$ in February 2018.

During the second major event, flowering had a first peak at $2400 \mathrm{~m}$ in October 2018, although with just three inflorescences, at 2600 and $2800 \mathrm{~m}$ in November, and $3000 \mathrm{~m}$ in February 2019 . Fruiting peaks started at $2400 \mathrm{~m}$ in May 2019 and ascended along the gradient to $2600 \mathrm{~m}$ (June), $2800 \mathrm{~m}$ (October), ending at $3000 \mathrm{~m}$ in January 2020. For each elevation, 24 months elapsed between the two major flowering peaks and 22-24 months between the two major fruiting peaks (Fig. 3). In the first major fruiting event there were 369 infructescences, whereas in the second major event they were 256 (Fig. 3). Because of the steep terrain, the great abundance of palms and the strikingness of ripe infructescences, the altitudinal shift of the fruiting process is an appealing feature of the basin's landscape.

In addition to the two major flowering events mentioned above, there were two minor ones: the first between October 2017 and April 2018, and another between July and September 2019. At the peaks of these events, the number of inflorescences produced was 6-24 times smaller than in the major ones. During these minor events, there were no inflorescences at some sites (Fig. 4).

Furthermore, the reproductive behavior of pistillate individuals was clearly related to elevation (Watson $\mathrm{U}^{2}$ test, Table 3). While the number of palms that went through two flowering and fruiting cycles increased uphill (4 individuals at $2400 \mathrm{~m}, 11$ individuals at 2600 $\mathrm{m}, 15$ individuals at $2800 \mathrm{~m}, 20$ individuals at $3000 \mathrm{~m}, \mathrm{~N}=80$ individuals), the number of palms with a single cycle decreased (16 individuals at $2400 \mathrm{~m}, 9$ individuals at 2600

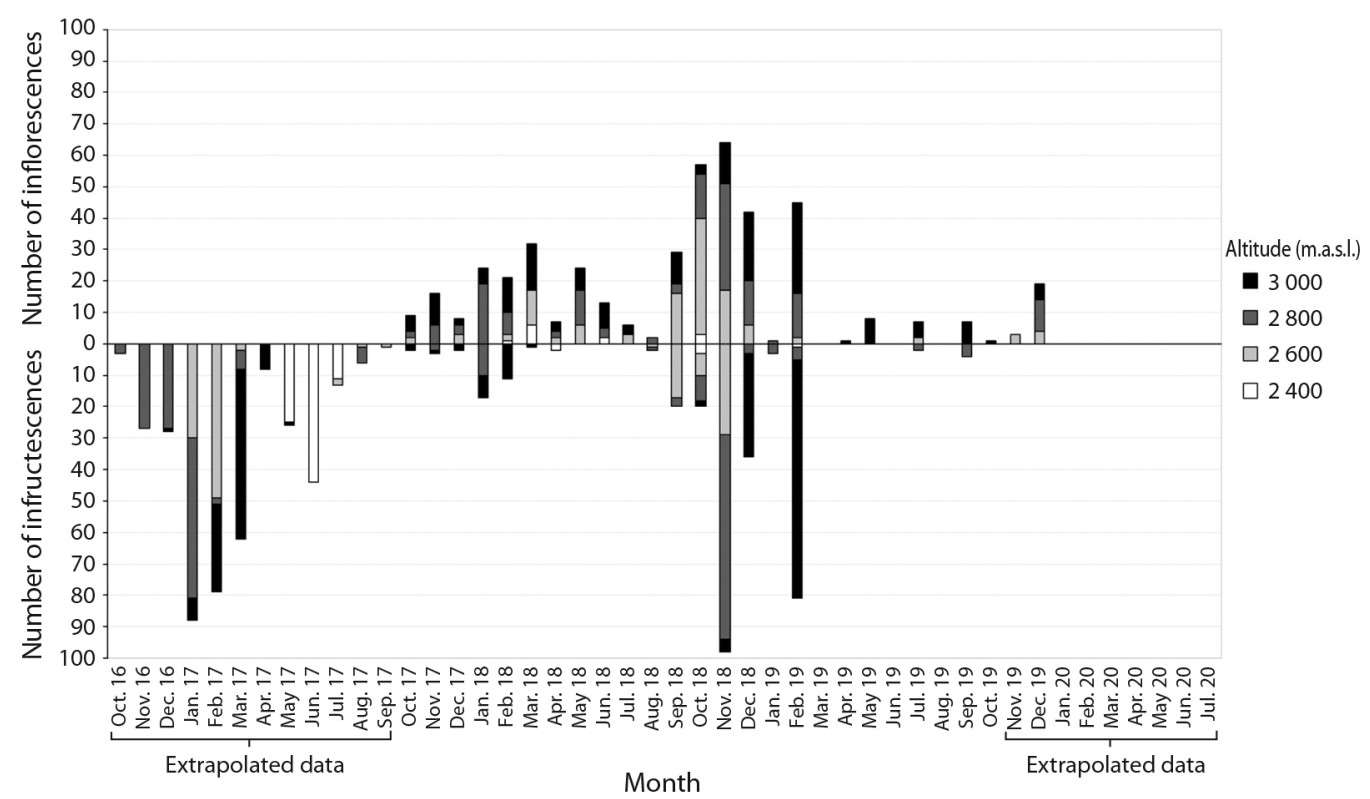

Fig. 4. Number of staminate and pistillate inflorescences of Ceroxylon quindiuense at the Tochecito River basin, Colombia, at four elevations (2400 to 3000 m.a.s.l.), between 2016 and 2020. 
$\mathrm{m}, 4$ individuals at $2800 \mathrm{~m}, 0$ individuals at $3000 \mathrm{~m}, \mathrm{~N}=80$ individuals). The total number of infructescences per cycle also increased with elevation (cycle one: 74 infructescences at $2400 \mathrm{~m}, 85$ infructescences at $2600 \mathrm{~m}, 115$ infructescences at $2800 \mathrm{~m}, 105$ infructescences at $3000 \mathrm{~m}, \mathrm{~N}=80$ individuals; cycle two: 5 infructescences at $2400 \mathrm{~m}, 54$ infructescences at $2600 \mathrm{~m}, 59$ infructescences at $2800 \mathrm{~m}, 114$ infructescences at $3000 \mathrm{~m}, \mathrm{~N}=80$ individuals), regardless of the number of cycles.

The average number of inflorescences produced per individual for the first major flowering event was $5.3(\mathrm{~N}=72, \mathrm{SD}=2.1)$ and, for the second, $5.1(\mathrm{~N}=50, \mathrm{SD}=2.3)$. Not all individuals flowered and fruited in every reproductive event. During the study period, $60 \%$ of the 80 pistillate individuals went through two flowering and fruiting cycles, whereas $39 \%$ only one. A single individual, at $2800 \mathrm{~m}$ elevation, went through three flowering cycles (December 2016, January 2018, November 2018).

The average number of infructescences produced per individual for the two major fruiting events was $5.3\left(\mathrm{~N}_{1}=69, \mathrm{~N}_{2}=50, \mathrm{SD}_{1}\right.$, $\mathrm{SD}_{2}=2.2$ ). The average number of fruits per infructescence was $4465(\mathrm{~N}=6, \mathrm{SD}=1488)$. The fresh weight of each fruit was on average $2.5 \mathrm{~g}(\mathrm{~N}=100, \mathrm{SD}=0.3 \mathrm{~g})$ and the weight of the edible fleshy pericarp was $1.15 \mathrm{~g}(\mathrm{~N}=100)$.

The data for staminate inflorescences cannot be extrapolated, so we only included two-year data. Furthermore, because of the ephemeral anthesis of the inflorescence and the persistence of old inflorescences for several months (personal observation; Carreño-Barrera et al., 2013), it was not easy to individually monitor each structure in its old inflorescence stage. For this reason, we only considered those inflorescences that we observed at anthesis or whose flowering had evidently taken place a few days before our observation. During the two years of our study, there were always at least a few staminate inflorescences in the basin. At our sampling sites, there were only two months (March and August 2019) in which no palm had any inflorescences.
But amid this year-round staminate flowering, two groups of well-defined peaks were evident at each altitude (Fig. 4) (Rao's Spacing Test $\mathrm{P}<0.01$, length of mean vector $>0.1)$. At elevations 2800 and $3000 \mathrm{~m}$., the length of the mean vector had values close to zero $(0.292$ and 0.164 , respectively), which shows that although there is a seasonality, it is not very well marked. A minor peak occurred between January and March 2018, and another one, almost twice as large, between October 2018 and February 2019. The largest of these groups of peaks coincided with the second major pistillate flowering event. The smaller of them largely matched the minor pistillate flowering event between January and April 2018 (Fig. 4).

The number of leaves in the crown was $12-27(\mathrm{Me}=18, \mathrm{SD}=2.4, \mathrm{~N}=160)$ and the median number of leaves produced per individual in 18 months was eight $(\mathrm{N}=83, \mathrm{SD}=$ 2.2 ), that is, 5.3 leaves per year (one leaf every 69 days). There was no difference in leaf production rate among elevations $(\chi 2=1.9844, \mathrm{P}$ $=0.3708)$, or between staminate and pistillate individuals $(\chi 2=0.45817, \mathrm{P}=0.4985)$. Each fallen leaf weighted $2.86 \mathrm{~kg}$ on average $(\mathrm{N}=$ $66, \mathrm{SD}=1.3 \mathrm{~kg}$ ). On the other hand, the average weight of an old male inflorescence was $1.84 \mathrm{~kg}(\mathrm{~N}=20, \mathrm{SD}=1.12 \mathrm{~kg})$, whereas old infructescences weighted $2.35 \mathrm{~kg}(\mathrm{~N}=15$, $\mathrm{SD}=0.97 \mathrm{~kg}$ ).

Although the overall trend of flowering graphically suggests a higher production of female inflorescences when rainfall decreases (Fig. 5), statistically there was no significant correlation $\left(\mathrm{R}_{\mathrm{S}}=-0.107236, \mathrm{P}=0.4832\right)$. The number of infructescences produced in the basin and the precipitation did not show a statistically significant correlation either $\left(\mathrm{R}_{\mathrm{S}}=\right.$ $-0.0105917, \mathrm{P}=0.9449$ ).

\section{DISCUSSION}

The sequential flowering of $C$. quindiuense along the altitudinal gradient at our study site probably plays the same role as the orchestrated flowering of several species growing along a gradient elsewhere in the Colombian 


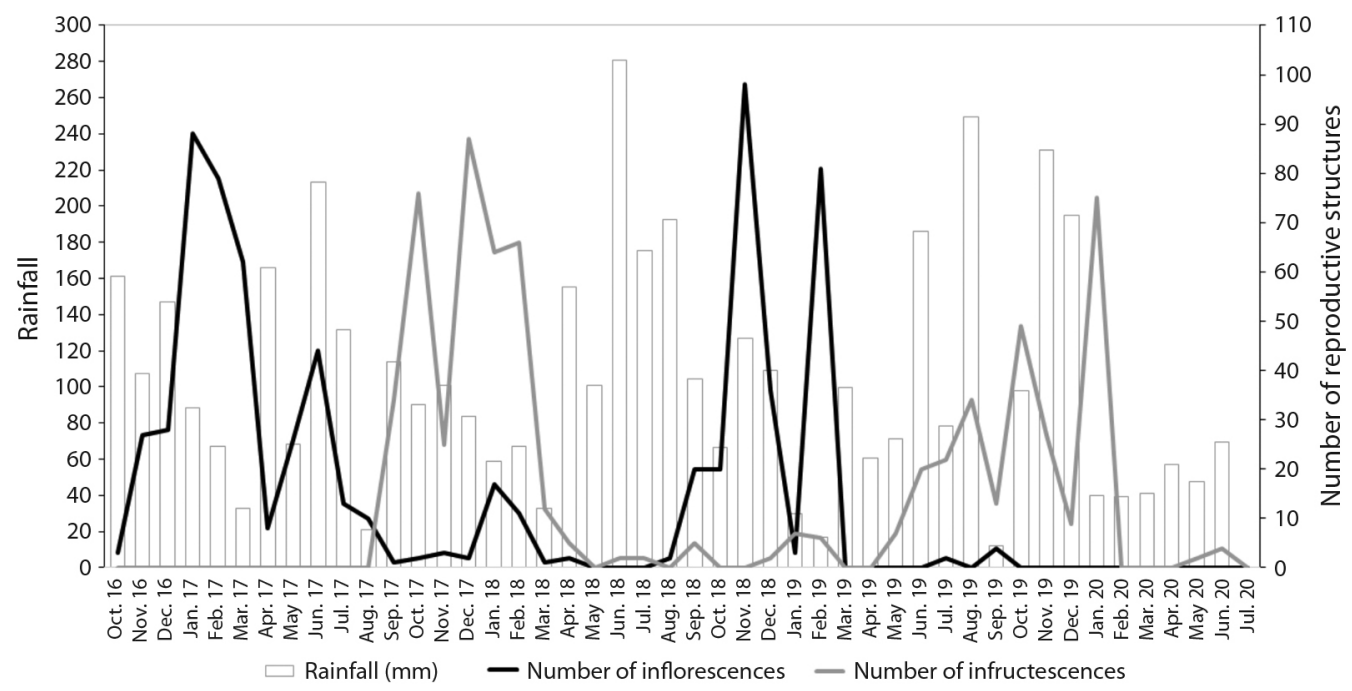

Fig. 5. Monthly pistillate flowering and fruiting of Ceroxylon quindiuense at the Tochecito River basin, Colombia, between 2016 and 2020, combined with rainfall data for the area. Rainfall data from IDEAM, Toche Climatological Station (21210180) (IDEAM, 2020).

Andes, as described by Carreño-Barrera et al. (2020), as a mechanism to enhance pollination. The staminate flowers of $C$. quindiuense are a vital food source and a place of reproduction for several species of nitidulid beetles of the genus Mystrops, the main pollinators of Ceroxylon species (Carreño-Barrera et al., 2020). The insects and the palms maintain a close relationship of pollinator-plant specificity that makes them highly dependent on each other. To maintain pollinator populations, palms of the genus Ceroxylon have developed strategies that allow them to have a constant supply of pollen for the beetles. Where several Ceroxylon species co-occur, one of these strategies is the asynchronous flowering of the different Ceroxylon species along the gradient, so that there is a steady offer of flowers over a long period of time (Carreño-Barrera et al., 2020).

At our study area, however, this strategy would not work, as there is only one other species of Ceroxylon in the basin, C. parvifrons, represented by just a handful of individuals (ca. ten detected by us so far), growing above the upper limit of the large stands of $C$. quindiuense. A long-term phenological study of $C$. quindiuense along an elevational gradient, in an area where other species of the genus cooccur, as in Southern Colombia, would help to test this hypothesis.

During the seven-month flowering season of $C$. quindiuense at our study sites, the populations of nitidulids probably migrate along the altitudinal gradient, following the offer of food and breeding sites. In the months when flowering is less abundant, the populations of Mystrops spp. probably undergo a significant decline, and these insects would survive on the isolated palms that flower asynchronously throughout the year. This pattern of isolated flowering individuals that maintain the pollinator's population has also been found for staphylinids associated with Phytelephas macrocarpa (as P. seemannii), another dioecious palm related to Ceroxylon (Bernal \& Ervik, 1996). Thus, highly specialized nitidulid species associated with wax palms depend on healthy and large population of their hosts for local persistence. As wax palm populations dwindle, there will be lesser chances for these beetle species to survive. 
Another strategy for maintaining pollinator populations in our study area is probably the reproductive alternation between individuals in the population over the years. Whereas $60 \%$ of the observed individuals went through two flowering cycles during the 44 months of the study, $39 \%$ of them went through a single cycle. The gradual increase, along the elevation gradient, both in the number of individuals with two cycles and in the total number of infructescences produced, results in an altitudinal shift of the number of flowers and fruits available in the basin.

Moreover, the finding of an individual that had three flowering cycles and another that only flowered in abundance once after many months of having no reproductive evidence suggests that there could be at least three flowering frequencies in the basin, with different amplitudes. The occasional synchrony of these three frequencies would explain the periodic occurrence of a large $C$. quindiuense fruiting event in the Central Cordillera of Colombia, which has been reported to happen every six to seven years (Bernal et al., 2015).

On the other hand, the number of infructescences produced by the palms in each cycle was not the same. In the second fruiting cycle, the total number of infructescences at our study sites decreased from 399 to 262 . This alternation of high with lower production cycles, in which not all individuals produce fruits, is probably related to the severe stress suffered by the palms after a mass fruiting event (Bernal et al., 2015). In individuals that produce seven to nine infructescences, several leaves dry off shortly after the fruiting season, giving the palm a sickly appearance; however, palms recover completely after a few months. Those palms do not produce so many infructescences in their next cycle, or even do not produce any infructescence at all, as might be the case with individuals that had only one cycle.

The anomalous behavior of the sampling site located at $2400 \mathrm{~m}$ is particularly interesting. This site had a different male:female ratio than the other three sites (2:3 vs. 1:1); five individuals that changed sex (four from male to female and one from female to male) (Martínez et al., 2018); and an adult individual that never exhibited any reproductive structures. Moreover, this site had the highest number of palms with a single fruiting cycle and the lowest total number of infructescences. Interestingly, the $2400 \mathrm{~m}$ site is at the lower limit of the huge palm stands of this basin; although $C$. quindiuense is distributed there from 2000 to 3100 $\mathrm{m}$, only isolated individuals are found below $2400 \mathrm{~m}$, often on very steep slopes.

The number of adult palms in the Tochecito River basin has been estimated between 256158 (Jiménez, 2017) and 600000 (Bernal et al., 2015; Instituto Humboldt, 2016), and the proportion of pistillate individuals to staminate between 1:1 (Girón-Vanderhuck et al., 2001a; Sanín, 2013; Sanín, Anthelme, Pintaud, Galeano, \& Bernal, 2013; Bernal et al., 2015) and 1:2 (Jiménez, 2017). Table 4 shows the estimated fruit production, based on data reported by Jiménez (2017) and Bernal et al. (2015) and Instituto Humboldt (2016), taking the area reported by Castillo and Díaz (2016).

Ceroxylon quindiuense fruits are consumed by numerous species of birds, as Green Jay (Cyanocorax yncas), Crimson-Rumped Toucanet (Aulacorhynchus prasinus), Black-Billed Mountain Toucan (Andigena nigrirostris), thrushes (Turdus spp.), parrots (Hapalopsittaca fuertesi, $H$. amazonina and Ognorhynchus icterotis) (Galeano \& Bernal, 2010; Sanín \&

TABLE 4

Fruit production of Ceroxylon quindiuense by reproductive event in the Tochecito River basin, Tolima, Colombia

\begin{tabular}{lcccc}
$\begin{array}{c}\text { Source for estimation of } \\
\text { the number of individuals and } \\
\text { the proportion of sexes }\end{array}$ & $\begin{array}{c}\text { Number of adult } \\
\text { female individuals }\end{array}$ & $\begin{array}{c}\text { Number of } \\
\text { infructescences } \\
\text { produced }\end{array}$ & Number of fruits & $\begin{array}{c}\text { Overall weight of the } \\
\text { edible fleshy pericarp (t) }\end{array}$ \\
Jiménez (2017) & 85385 & 452540 & 2020293333 & 2324 \\
Bernal et al. (2015) & 300000 & 1590000 & 7099350000 & 8164 \\
\hline
\end{tabular}


Galeano, 2011; Bernal et al., 2015). The huge number of fruits produced during a fruiting event (between 2.0 and 7.1 billion fruits) represents a supply of edible pulp of 2324-8 164 tons over an eight-month period. The altitudinal shift of this food supply should have a tremendous impact on the associated fauna and probably causes altitudinal migrations of animals in the basin, as has already been documented for other plant species at various sites (e.g., Levey, 1988; Loiselle \& Blake, 1991; Laps, 1996; Kimura, Yumoto, \& Kikuzawa, 2001; Malizia, 2001; Castro, Galetti, \& Morellato, 2007).

During the twelve months in which few or no fruits of $C$. quindiuense are available in the basin, the frugivores must turn to other food sources. In the Tochecito River basin there are at least 237 species of trees and shrubs (GirónVanderhuck, Agudelo, \& Macías, 2001b), among which we have identified at least 101, mainly in the families Solanaceae, Melastomataceae, Myrsinaceae, Rubiaceae and Lauraceae; that could be potential food sources for the fauna in times when Ceroxylon fruits are not available. Information on the phenological cycles of these species and the quantification of their food supply are vital for understanding the spatial and temporal dynamics of the fauna associated with $C$. quindiuense.

Besides its impact on the populations of pollinators and frugivores, C. quindiuense has another major effect on the ecosystems in the double-canopy forests of this basin, where the palms make "a forest above the forest". With the large number of adult palms, each producing 5.3 leaves per year and each of these with an associated old inflorescence or old infructescence, the palm's contribution of biomass to the basin (not including flowers and fruits) is estimated to be 6 605-15 739 tons per year, i.e., ca. 3-7.2 tons per hectare. This astonishing amount of biomass, coming from an extra emergent canopy (not including that from the forest canopy below) could make Tochecito and its palm-rich forests one of the most productive ecosystems in the high Andes. For example, Vitousek (1984) and Wallis et al. (2019) have reported annual values of 3.7 to 11.6 tons of litter production per hectare in what we assume are single-canopy Neotropical mountain forests. Furthermore, the large size and weight of the leaves and old infructescences, and their fall from heights greater than $40 \mathrm{~m}$, undoubtedly have an important role in shaping regeneration in the palm-dominated forests. Because of this, conserving Ceroxylon quindiuense in the Tochecito River basin is vital for conserving the whole ecosystem in the area.

Ethical statement: authors declare that they all agree with this publication and made significant contributions; that there is no conflict of interest of any kind; and that we followed all pertinent ethical and legal procedures and requirements. All financial sources are fully and clearly stated in the acknowledgements section. A signed document has been filed in the journal archives.

\section{ACKNOWLEDGMENTS}

We thank the Cardona Lozano family (Marlene, Francis, Oscar, César, Leandro, Sarita, Osquítar), Francisco Javier Trujillo (Pachito) and his family, for their hospitality and friendship during the data collection time, William Vargas for information about the flora of the region, Steven Bernal, Arthur Campos and Javier Carreño for information about circular statistics, the Alexander von Humboldt Institute and Nature and Culture International for financial support, and Idea Wild for donation of equipment.

\section{RESUMEN}

\section{Fenología de la palma en peligro Ceroxylon quindiuense (Arecaceae) a lo largo de un gradiente altitudinal en Colombia.}

Introducción: Comprender la fenología de las poblaciones de plantas es vital para su conservación y manejo. Estudiamos la fenología vegetativa y reproductiva de la palma amenazada Ceroxylon quindiuense a lo largo de un gradiente altitudinal en la Cordillera Central de Colombia. Objetivo: Describimos la tasa de producción de hojas, los ciclos de floración y fructificación, y calculamos la oferta 
alimentaria para la fauna, como una herramienta para el adecuado manejo de la palma. Métodos: En cada sitio de muestreo (2400, 2600, 2800, 3000 m.s.n.m.), marcamos 40 individuos adultos (20 pistilados, 20 estaminados), que seguimos bimestralmente durante 24 meses. Estudiamos la producción de hojas contando las caídas al suelo. Seguimos la producción de flores y frutos a través de observaciones con binoculares y fotografías. Resultados: Cada individuo adulto produjo, en promedio, una hoja cada 69 días. Aunque los individuos aislados florecieron durante todo el año, la mayoría de las palmas florecieron sincrónicamente en cada elevación entre octubre 2016 y agosto 2017 y de agosto 2018 a febrero 2019 y tuvieron frutos maduros entre 7-13 meses después. La floración comenzó a los 2600 m, seguida de los 2800 y los $3000 \mathrm{~m}$. Las palmas a $2400 \mathrm{~m}$, límite inferior de los palmares de la zona, mostraron un comportamiento singular, con escasa producción de flores y frutos, varios individuos que cambiaron de sexo y una mayor proporción de palmas pistiladas. Cada palma produjo $1-11(\overline{\mathrm{x}}=5.3, \mathrm{SD}=2.2)$ inflorescencias y $1-10(\overline{\mathrm{x}}$ $=5.3, \mathrm{SD}=2.2$ ) infrutescencias. El número promedio de frutos por infrutescencia fue de 4465. Con una población estimada de palmas adultas entre 256000 y 600000 y una proporción total de individuos pistilados: estaminados 1:1 o 1:2, la producción total de frutos en el área durante cada período de fructificación se estima en 2.0-7.1 mil millones de frutos. Conclusiones: La gran cantidad de flores y frutos y su progresiva disponibilidad a lo largo del gradiente tienen un impacto importante en la distribución espacial y temporal de la oferta de alimento para la fauna asociada a la palma.

Palabras clave: gradiente altitudinal; floración; fructificación; producción de hojas; fenología de palmas.

\section{REFERENCES}

Beck, H. (2007). Synergistic impacts of ungulates and falling palm fronds on saplings in the Amazon. Journal of Tropical Ecology, 23(5), 599-602.

Bernal, R. (1992). Colombian palm products. In M. Plotkin \& L. Famolare (Eds.), Sustainable harvest and marketing of rain forest products (pp. 158-172). Washington D.C., USA: Island Press.

Bernal, R., \& Ervik, F. (1996). Floral biology and pollination of the dioecious palm Phytelephas seemannii in Colombia: An adaptation to Staphylinid beetles. Biotropica, 28(4), 682-696.

Bernal, R., \& Galeano, G. (2013). Cosechar sin destruirAprovechamiento sostenible de palmas colombianas. Bogotá, Colombia: Instituto de Ciencias Naturales, Universidad Nacional de Colombia Press.

Bernal, R., Galeano, G., \& Sanín, M.J. (2015). Plan de conservación, manejo y uso sostenible de la palma de cera del Quindio (Ceroxylon quindiuense), Árbol
Nacional de Colombia. Bogotá, Colombia: Ministerio de Ambiente y Desarrollo Sostenible - Universidad Nacional de Colombia Press.

Bernal, R., Martínez, B., \& Sanín, M.J. (2018). The world's tallest palms. Palms, 62(1), 5-16.

Cabrera, H., \& Wallace, R. (2007). Patrones fenológicos de ocho especies de palmeras en un bosque amazónico de Bolivia. Revista Boliviana de Ecología y Conservación Ambiental, 21(1), 1-18.

Carreño-Barrera, J., Madriñán, S., \& Núñez-Avellaneda, L.A. (2013). Ecología de la polinización de tres palmas de cera (Ceroxylon parvifrons, C. ventricosum y C. vogelianum) coexistentes en el sur de los Andes de Colombia (Tesis de Maestría). Universidad de los Andes, Bogotá, Colombia. Retrieved from https:// repositorio.uniandes.edu.co/handle/1992/11983

Carreño-Barrera, J., Núñez-Avellaneda, L.A., Sanín., M.J., \& Campos, A. (2020). Orchestrated flowering and interspecific facilitation: Key factors in the maintenance of the main pollinator of coexisting threatened species of Andean wax palms (Ceroxylon spp.). Annals of the Missouri Botanical Garden, 105(3), 281-299.

Castillo, L.S., \& Díaz, J. (2016). Resumen descriptivo de las unidades de cobertura de la tierra para Tochecito. Instituto de Investigación de Recursos Biológicos Alexander von Humboldt y Naturaleza y Cultura Internacional. (Unpublished report).

Castro, E.R., Galetti, M., \& Morellato, P.C. (2007). Reproductive phenology of Euterpe edulis (Arecaceae) along a gradient in the Atlantic rainforest of Brazil. Australian Journal of Botany, 55(7), 725-735.

Corner, E. (1966). The Natural History of Palms. London, UK: Weindenfeld and Nicholson Press.

Galeano, G., \& Bernal, R. (2005). Palmas (familia Arecaceae o Palmae). En E. Calderón, G. Galeano, \& N. García (Eds.), Libro Rojo de Plantas de Colombia (pp. 59-223). Bogotá, Colombia: Ministerio de Ambiente, Vivienda y Desarrollo Territorial/ Instituto Alexander von Humboldt/Instituto de Ciencias Naturales Press.

Galeano, G., \& Bernal, R. (2010). Palmas de Colombia: guía de campo. Bogotá, Colombia: Instituto de Ciencias Naturales, Universidad Nacional de Colombia Press.

Galetti, M., Ziparro, V., \& Morellato, L.P. (1999). Fruit phenology and frugivory on the palm Euterpe edulis in a lowland Atlantic forest of Brazil. Ecotropica, 5, 115-122.

Genini, J., Galetti, M., \& Morellato, L.P. (2009). Fruit phenology of palms and trees in an Atlantic rainforest land-bridge island. Flora, 204(2), 131-145. 
Giombini, M.A., Bravo, S.P., \& Tosto, D.S. (2016). Seed dispersal of the palm Syagus romanzoffiana by tapirs in the semi-deciduos Atlantic forest of Argentina. Biotropica, 41(4), 408-413.

Girón-Vanderhuck, M., Salazar, G.E., \& Agudelo, F.D. (2001a). Estructura poblacional de la palma de cera Ceroxylon quindiuense (Karst.) H. Wendl. en Toche, Tolima. En M. Girón-Vanderhuck (Ed.), Bosques de palma de cera (pp. 31-41). Armenia, Colombia: Universidad del Quindío Press.

Girón-Vanderhuck, M., Agudelo, C.A., \& Macías, D. (2001b). Estructura y diversidad florística de tres bosques de palma de cera. En M. Girón-Vanderhuck (Ed.), Bosques de Palma de Cera (pp. 127-157). Armenia, Colombia: Universidad del Quindío Press.

Henderson, A. (2002). Evolution and Ecology of Palms. New York, USA: The New York Botanical Garden Press.

Henderson, A., Galeano, G., \& Bernal, R. (1995). Field Guide to the Palms of the Americas. Princeton, USA: Princeton University Press.

Instituto Humboldt (Instituto de Investigación de Recursos Biológicos Alexander von Humboldt). (2016). Propuesta para la creación de un santuario de flora nacional para la Palma de Cera (Ceroxylon quindiuense) (Unpublished report).

IDEAM (Instituto de Hidrología, Meteorología y Estudios Ambientales). (2020). Consulta y Descarga de Datos Hidrometeorológicos. Retrieved from http://dhime. ideam.gov.co/atencionciudadano

IGAC (Instituto Geográfico Agustín Codazzi). (2014). Base cartográfica integrada a escala 1:100.000 en formato Geodatabase, actualizada a 2014. Retrieved from https://geoportal.igac.gov.co/contenido/ datos-abiertos-cartografia-y-geografia

Jiménez, I. (2017). Estado actual de conservación de la población de Ceroxylon quindiuense (H. Karst.) H.Wendl (Arecaceae) en la microcuenca del río Tochecito, Tolima (Tesis de pregrado). Pontificia Universidad Javeriana, Bogotá, Colombia.

Johnson, D. (2011). Non wood forest products. Tropical Palms. Rome, Italy: Food and Agriculture Organization of the United Nations.

Keuroghlian, A., \& Eaton, D.P. (2009). Removal of palm fruits and ecosystem engineering in palm stands by white-lipped peccaries (Tayassu pecari) and other frugivores in an isolated Atlantic Forest fragment. Biodiversity and Conservation, 18(7), 1733-1750.

Kimura, K., Yumoto, T., \& Kikuzawa, K. (2001). Fruiting phenology of fleshy-fruited plants and seasonal dynamics of frugivorous birds in four vegetation zones on Mt. Kinabalu, Borneo. Journal of Tropical Ecology, 17(6), 833-858.
Kovach, W.L. (1994). Program: Oriana for Windows (Version 4.02). Retrieved from https://www.kovcomp. co.uk/oriana

Laps, R.R. (1996). Frugivoria e dispersão de sementes de palmiteira (Euterpe edulis, Martius, Arecaceae) na Mata Atlantica, sul do Estado de São Paulo (Master's thesis). Universidade Estadual de Campinas, Instituto de Biologia, Campinas, São Paulo, Brazil. Retrieved from http://www.repositorio.unicamp.br/ handle/REPOSIP/316282

Levey, D.J. (1988). Spatial and temporal variation in Costa Rican fruit and fruit-eating bird abundance. Ecological Monographs, 58(4), 251-26.

Loiselle, B.A., \& Blake, J.G. (1991). Temporal variation in birds and fruits along an elevational gradient in Costa Rica. Ecology, 72(1), 180-193.

Malizia, L. (2001). Seasonal fluctuations of birds, fruits, and flowers in a subtropical forest of Argentina. The Condor, 103(1), 45-61.

Martínez, B., Sanín, M.J., Castillo, L.S., López, R., \& Bernal, R. (2018). Sex change in the dioecious palm Ceroxylon quindiuense (Arecaceae). Ecology, 99(6), 1501-1503.

Morellato, L.P., Talora, D.C., Takahasi, A., Bencke, C., Romera, E., \& Ziparro, V. (2000). Phenology of Atlantic rain forest trees: a comparative study. Biotropica, 32(4b), 811-823.

Peres, C. (1994). Composition, density, and fruiting phenology of arborescent palms in an Amazonian terra firme forest. Biotropica, 26(3), 285-294.

Ramírez, J.J., Roldán, P.G., \& Yépez, G.A. (2004). Altitudinal Variation of the Numerical Structure and Biodiversity of the Taxocenosis of Ephemeroptera in the South, North, and Central Regions of the Department of Antioquia, Colombia. Acta Limnologica Brasiliensia, 16(4), 329-339.

Salm, R., Jalles-Filho, E., \& Schuck-Paim, C. (2005). A model for the importance of large arborescent palms in the dynamics of seasonally-dry Amazonian forests. Biota Neotropica, 5(2), 151-156.

Sanín, M.J. (2013). Estudios ecológicos y Evolutivos en Ceroxylon (Palmae: Ceroxyloideae) (Doctoral dissertation). Universidad Nacional de Colombia, Bogotá, Colombia. Retrieved from https://docplayer. es/47608857-Estudios-ecologicos-y-evolutivos-enceroxylon-palmae-ceroxyloideae.html

Sanín, M.J., \& Galeano, G. (2011). A revision of the Andean wax palms, Ceroxylon (Arecaceae). Phytotaxa, 34(1), 1-64.

Sanín, M.J., Anthelme, F., Pintaud, J.C., Galeano, G., \& Bernal, R. (2013). Juvenile resilience and adult longevity explain residual populations of the Andean 
Wax Palm Ceroxylon quindiuense after deforestation. PLoS One, 8(10), e74139.

Sayer, E.J., Rodtassana, C., Sheldrake, M., Bréchet, L.M., Ashford, O.S., Lopez-Sangil, L., ... Tanner, E.V.J. (2020). Revisiting nutrient cycling by litterfall Insights from 15 years of litter manipulation in old-growth lowland tropical forest. Advances in Ecological Research, 62, 173-223.

Scariot, A. (1999). Forest fragmentation effects on palm diversity in Central Amazonia. Journal of Ecology, 87(1), 66-76.

Tomlinson, P.B. (1963). Measuring growth rates in palms. Principes, 7(1), 40-44.

Vitousek, P.M. (1984). Litterfall, nutrient cycling, and nutrient limitation in tropical forest. Ecology, 65(1), 285-298.
Wallis, C.I.B., Homeier, J., Peña, J., Brandl, R., Farwig, N., \& Bendix, J. (2019). Modeling tropical montane forest biomass, productivity and canopy traits with multispectral remote sensing data. Remote Sensing of Environment, 225(1), 77-92.

Young, H.S., Raab, T.K., McCauley, D.J., Briggs, A.A., \& Dirso, R. (2010). The coconut palm, Cocos nucifera, impacts forest composition and soil characteristics at Palmyra Atoll, Central Pacific. Journal of Vegetation Science, 21(6), 1058-1068.

Zar, J.H. (1999). Biostatistical Analysis. New Jersey, USA: Prentice-Hall.

Zona, S., \& Henderson, A. (1989). A review of animalmediated seed dispersal of palms. Selbyana, 11, 6-21. 